\title{
Influence of Exogenous Compounds and Maize Crop Residue on Biological Activities in Salt Affected Soil
}

\author{
Anjali Bhadra Vijay* and P. Prasuna Rani \\ Department of Soil Science and Agricultural Chemistry, \\ Agricultural College, Bapatla-522 101, India \\ *Corresponding author
}

\section{A B S T R A C T}

\begin{tabular}{|l|}
\hline Ke y w or d s \\
soil properties \\
$\begin{array}{l}\text { DEH enzyme } \\
\text { maize } \\
\text { proline / } \mathrm{KNO}_{3}\end{array}$ \\
\hline Article Info \\
\hline $\begin{array}{l}\text { Accepted: } \\
\text { 20 May } 2020 \\
\text { Available Online: } \\
\text { 10 June } 2020\end{array}$ \\
\hline
\end{tabular}

Amelioration of salt-affected soils requires an integrated management approach, which not only improves their effectiveness for improving soil properties, but also increases the crop performance and stress tolerance ability of the crop. Hence, a green house experiment was conducted to determine the effect of integrated use of crop residue and inorganic source of fertilizers with exogenous foliar sprays on soil microbial population and DEH enzyme activity of maize grown saline soil (ECe 6.2 $\mathrm{dS} \mathrm{\textrm {m } ^ { - 1 }}$ ). Treatments included: $100 \%$ RDFN (Recommended dose of nitrogen fertilizers) $\left(\mathrm{T}_{1}\right) ; 25 \%$ extra nitrogen through inorganic fertilizers $\left(\mathrm{T}_{2}\right) ; 25 \%$ extra $\mathrm{N}$ through raw residue $\left(\mathrm{T}_{3}\right) ; 25 \%$ extra $\mathrm{N}$ through compost $\left(\mathrm{T}_{4}\right)$; and combination of $\mathrm{T}_{2}, \mathrm{~T}_{3}$ and $\mathrm{T}_{4}$ treatments with exogenous foliar sprays humic acid / proline / $\mathrm{KNO}_{3}$ in a CRD layout. Result obtained at various stages of crop growth indicated a steady increase in bacterial, fungi, actinomycetes count and dehydrogenase enzyme activty startng from inital stage with more pronounced influence on fungal colonies as ther are more senstive to abotic stress with integrated application of crop residue and exogenous spray. Highest population of $21.33 \times 10^{5}, 13.00 \times 10^{3}, 20.67 \times 10^{4}$ bacteria, fungi, actinomycetes, respectively and the highest dehydrogenase activity of $36.67 \mu \mathrm{g} \mathrm{g}^{-1}$ of TPF $\mathrm{g}^{-1}$ day $^{-1}$ was observed in compost amended treatment $\left(\mathrm{T}_{13}\right)$ along with $\mathrm{KNO}_{3}$ foliar spray at tasseling.

\section{Introduction}

Soil salinity is a threat world-wide to agricultural production and ecosystems as it reduces plant growth through impaired nutrient uptake and microbial functioning. Soluble salts increase the osmotic potential of the soil water, draws water out of cells thereby kill microbes and roots through plasmolysis.

Plants and microbes can adapt to low osmotic potential by accumulating osmolytes, however; synthesis of osmolytes requires large amounts of energy and these results in reduced growth and activity. Crop residues hold great promise due to their local availability as a source of multiple nutrients and ability to improve soil characteristics. Application of organic matter alone to soil is not a complete substitute for inorganic fertilizer and their roles are complementary to each other. Supplementation of energy through crop residue as nutrient sources for microbes may be an important strategy to ameliorate saline soils. 


\section{Materials and Methods}

\section{Pot study and experimental arrangements}

The experiment was conducted in a green house at the Department of Soil Science \& Agricultural chemistry, Agricultural College Bapatla. Acharya N.G. Ranga Agriculture University during the Kharif season 2017 2018 using transported soil. The experimental soil characterized as clayey in texture, moderately alkaline with $\mathrm{pH} 8.20$, ECe $6.2 \mathrm{dS}$ $\mathrm{m}^{-1}$, organic carbon $5.76 \mathrm{~g} \mathrm{~kg}^{-1}$, available $\mathrm{N}$, $\mathrm{P}, \mathrm{K}, \mathrm{S}$ of $220,38.43,432 \mathrm{~kg} \mathrm{ha}^{-1}$ and 59.94 $\mathrm{mg} \mathrm{kg}^{-1}$.Required quantity of stover was allowed to dry and latter chopped into pieces for further use.

The required quantity of compost was prepared by the aerobic decomposition of maize stalk. For microbial and enzymatic activity, soil samples were collected at sowing, knee high, tasseling and harvest stages from the rhizosphere region and were stored in polythene bags at 2 to $4^{\circ} \mathrm{C}$ for as short time as possible until examination.

\section{Method adopted}

Bacteria, fungi and actinomycetes were estimated as per the procedures outlined by Paroda (2007). The enumeration of total bacteria in fresh soil samples were carried out by following serial dilution plate count technique (Dhingra and Sinclair, 2000) using nutrient agar medium (agar agar-20g; beef extract $-3 \mathrm{~g}$; peptone $-5 \mathrm{~g}$ solution; water -1 liter).

Total fungi using Martins rose bengal agar for fungi (Martin, 1950), actinomycetes with Khusters nutrient agar medium. Dehydrogenase activity in the soil sample was determined by following the procedure as described by Casida et al. (1964) using 2,3,5Triphenyltetrazolium chloride (TTC).

\section{Results and Discussion}

\section{Microbial population}

Microbial enumeration carried out at knee high, tasseling and harvest stage of maize growth revealed that application of organics alone and in combination with exogenous compounds created a favorable environment for flourishing microbial communities as evident from the increased dehydrogenase enzyme activity recorded.

\section{Bacteria}

At knee high and tasseling stages, maximum bacterial count of $19.00 \times 10^{5}$ and $21.33 \times 10^{5}$ $\mathrm{CFU}$, respectively was recorded in treatment supplied with $25 \%$ extra nitrogen as compost $+\mathrm{KNO}_{3}$ foliar spray $\left(\mathrm{T}_{13}\right)$ and it was at par with all treatments, which received compost $\left(\mathrm{T}_{12}, \mathrm{~T}_{11}\right.$ and $\left.\mathrm{T}_{4}\right)$ and significantly superior to remaining treatments except $\mathrm{T}_{10}$, which received (25\% extra nitrogen as raw residue + $\mathrm{KNO}_{3}$ foliar spray @ $10 \mathrm{~g} \mathrm{~L}^{-1}$ at 20 and 40 DAS) at tasseling stage.

All treatments supplied with raw residue recorded comparable values at knee high and tasseling stages. At harvest, among raw residue treatments, foliar spray of proline $\left(\mathrm{T}_{9}\right)$ and $\mathrm{KNO}_{3} \quad\left(\mathrm{~T}_{10}\right)$ were found to be significantly superior to others. The treatment supplied with $100 \%$ RDFN recorded the lowest population of $12.33,14.00$ and $10.00 \times$ $10^{5} \mathrm{CFU}$ at knee high, tasseling and harvest, respectively.(Table 1)

\section{Fungi}

At knee high, tasseling and harvest the highest population of $10.33,13.00$ and 10.00 $\times 10^{3}$ CFU was observed in treatment receiving $25 \%$ extra nitrogen through compost $+\mathrm{KNO}_{3}$ foliar spray @ $10 \mathrm{~g} \mathrm{~L}^{-1}$ at 20 and 40 DAS $\left(\mathrm{T}_{13}\right)$ it was at par with $\mathrm{T}_{11}(25 \%$ 
extra nitrogen through compost + humic acid @ $0.2 \%$ at 20 and 40 DAS) and $\mathrm{T}_{12}(25 \%$ extra nitrogen through compost + proline foliar spray @ $50 \mathrm{mM} \mathrm{L}^{-1}$ ) at tasseling and comparable with $\mathrm{T}_{11}$ at harvest and significantly superior to remaining treatment at different stages, while the lowest count of $2.00 \times 10^{3}, 3.00 \times 10^{3}, 1.00 \times 10^{3} \mathrm{CFU}$ ) was observed in treatments supplied with $100 \%$ RDFN (Table 2).

\section{Actinomycetes}

Treatment supplied with $25 \%$ extra nitrogen through compost $+\mathrm{KNO}_{3}$ foliar spray @ $10 \mathrm{~g}$ $\mathrm{L}^{-1}$ at 20 and 40 DAS $\mathrm{T}_{13}$ recorded the highest value of 19.67 and $20.67 \times 10^{4} \mathrm{CFU}$ and was significantly superior to the remaining treatments except the treatments $T_{12}$ and $T_{11}$ at knee high and tasseling.

While At harvest maximum population was observed in compost treatments supplemented with exogenous foliar spray $\left(\mathrm{T}_{13}, \mathrm{~T}_{12}\right.$, and T11). The lowest $\left(10.33,11.67\right.$ and $9.67 \times 10^{4}$ CFU) population was observed in $\mathrm{T}_{1}(100 \%$ RDF) at knee high, tasseling and harvest stages, respectively as presented in table 3 .

\section{Dehydrogenase enzyme activity}

At 30 and 60 DAS the highest dehydrogenase activity of 23.33 and $36.67 \mu \mathrm{g}$ of TPF $\mathrm{g}^{-1}$ day ${ }^{1}$ was recorded in treatments supplied with $25 \%$ extra nitrogen through compost + foliar spray of $\mathrm{KNO}_{3} @ 10 \mathrm{~g} \mathrm{~L}^{-1}$ at 20 and 40 DAS.

At harvest the maximum activity of $17.28 \mu \mathrm{g}$ of TPF $\mathrm{g}^{-1}$ day $^{-1}$ was recorded in treatment $\mathrm{T}_{12}$, supplied with compost and foliar spray of proline $50 \mathrm{mM} \mathrm{L}^{-1}$ at 20 and 40 DAS. The lowest dehydrogenase activity of $8.20,12.85$ and $6.77 \mu \mathrm{g}$ of TPF $\mathrm{g}^{-1} \mathrm{day}^{-1}$, was recorded in treatment supplied with recommended dose of fertilizers $\left(T_{1}\right)$ at knee high, tasseling and harvest, respectively (Table 4).

Table. 1 Influence of exogenous compounds and crop residues on bacterial population in soil at different stages of crop growth

\begin{tabular}{|c|c|c|c|}
\hline \multirow[t]{2}{*}{ Treatment } & \multicolumn{3}{|c|}{$\begin{array}{c}\text { Bacterial population } \\
\left(\times 10^{5} \mathrm{CFU} \mathrm{g}^{-1} \text { soil }\right)\end{array}$} \\
\hline & Knee high & Tasseling & Harvest \\
\hline $\mathrm{T}_{1}: 100 \% \mathrm{RDFN}$ & 12.33 & 14.00 & 10.00 \\
\hline $\mathrm{T}_{2}: 125 \% \mathrm{RDFN}$ & $13.33 d$ & 15.67 & 12.00 \\
\hline $\mathrm{T}_{3}: 100 \% \mathrm{RDFN}+25 \% \mathrm{RDN}$ as raw maize residue & 16.00 & 18.67 & 14.33 \\
\hline $\mathrm{T}_{4}: 100 \%$ RDFN $+25 \%$ RDN as maize compost & 18.00 & 20.33 & 16.33 \\
\hline $\mathrm{T}_{5}: \mathrm{T}_{2}+$ Humic acid foliar spray @ $0.2 \%$ at 20 and 40 DAS & 13.67 & 16.00 & 12.33 \\
\hline $\mathrm{T}_{6}: \mathrm{T}_{2}+$ Proline foliar spray @ $@ 50 \mathrm{mM} \mathrm{L}^{-1}$ at 20 and $40 \mathrm{DAS}$ & 14.33 & 16.33 & 13.00 \\
\hline $\mathrm{T}_{7}: \mathrm{T}_{2}+\mathrm{KNO}_{3}$ foliar spray @10 $\mathrm{g} \mathrm{L}^{-1}$ at 20 and $40 \mathrm{DAS}$ & 14.67 & 17.00 & 13.67 \\
\hline $\mathrm{T}_{8}: \mathrm{T}_{3}+$ Humic acid foliar spray @ $0.2 \%$ at 20 and 40 DAS & 16.00 & 19.33 & 14.67 \\
\hline $\mathrm{T}_{9}: \mathrm{T}_{3}+$ Proline foliar spray @ $50 \mathrm{mM} \mathrm{L}^{-1}$ at 20 and $40 \mathrm{DAS}$ & 16.33 & 18.33 & 15.67 \\
\hline $\mathrm{T}_{10}: \mathrm{T}_{3}+\mathrm{KNO}_{3}$ foliar spray @10 g L ${ }^{-1}$ at 20 and $40 \mathrm{DAS}$ & 17.00 & 20.00 & 16.00 \\
\hline $\mathrm{T}_{11}: \mathrm{T}_{4}+$ Humic acid foliar spray @ $0.2 \%$ at 20 and 40 DAS & 19.00 & 20.33 & 17.33 \\
\hline $\mathrm{T}_{12}: \mathrm{T}_{4}+$ Proline foliar spray @ $50 \mathrm{mM} \mathrm{L}^{-1}$ at 20 and $40 \mathrm{DAS}$ & 18.67 & 20.67 & 17.67 \\
\hline $\mathrm{T}_{13}: \mathrm{T}_{4}+\mathrm{KNO}_{3}$ foliar spray @10 $\mathrm{g} \mathrm{L}^{-1}$ at 20 and $40 \mathrm{DAS}$ & 19.00 & 21.33 & 17.33 \\
\hline SEm \pm & 0.40 & 0.48 & 0.39 \\
\hline CD@0.05 & 1.22 & 1.46 & 1.19 \\
\hline $\mathrm{CV}(\%)$ & 4.36 & 4.55 & 4.64 \\
\hline
\end{tabular}


Table.2 Influence of exogenous compounds and crop residues on fungal population in soil at different stages of crop growth

\begin{tabular}{|c|c|c|c|}
\hline \multirow[t]{2}{*}{ Treatment } & \multicolumn{3}{|c|}{$\begin{array}{l}\text { Fungal population } \\
\left(\times 10^{3} \mathrm{CFU} \mathrm{g}^{-1} \text { soil }\right)\end{array}$} \\
\hline & Knee high & Tasseling & Harvest \\
\hline $\mathrm{T}_{1}: 100 \% \mathrm{RDFN}$ & 2.00 & 3.00 & 1.00 \\
\hline $\mathrm{T}_{2}: 125 \% \mathrm{RDFN}$ & 2.67 & 4.33 & 2.00 \\
\hline $\mathrm{T}_{3}: 100 \% \mathrm{RDFN}+25 \% \mathrm{RDN}$ as raw maize residue & 4.00 & 8.00 & 3.67 \\
\hline $\mathrm{T}_{4}: 100 \% \mathrm{RDFN}+25 \% \mathrm{RDN}$ as maize compost & 8.67 & 10.00 & 6.33 \\
\hline $\mathrm{T}_{5}: \mathrm{T}_{2}+$ Humic acid foliar spray @ $0.2 \%$ at 20 and $40 \mathrm{DAS}$ & 2.67 & 5.00 & 1.67 \\
\hline $\mathrm{T}_{6}: \mathrm{T}_{2}+$ Proline foliar spray @50 $\mathrm{mM} \mathrm{L}^{-1}$ at 20 and $40 \mathrm{DAS}$ & 3.33 & 5.33 & 3.00 \\
\hline $\mathrm{T}_{7}: \mathrm{T}_{2}+\mathrm{KNO}_{3}$ foliar spray @ $10 \mathrm{~g} \mathrm{~L}^{-1}$ at 20 and $40 \mathrm{DAS}$ & 3.00 & 5.00 & 3.33 \\
\hline $\mathrm{T}_{8}: \mathrm{T}_{3}+$ Humic acid foliar spray @ $0.2 \%$ at 20 and $40 \mathrm{DAS}$ & 6.67 & 8.67 & 4.00 \\
\hline $\mathrm{T}_{9}: \mathrm{T}_{3}+$ Proline foliar spray @ $50 \mathrm{mM} \mathrm{L}^{-1}$ at 20 and $40 \mathrm{DAS}$ & 7.00 & 9.00 & 4.67 \\
\hline $\mathrm{T}_{10}: \mathrm{T}_{3}+\mathrm{KNO}_{3}$ foliar spray @10 $\mathrm{g} \mathrm{L}^{-1}$ at 20 and $40 \mathrm{DAS}$ & 7.00 & 8.67 & 5.67 \\
\hline $\mathrm{T}_{11}: \mathrm{T}_{4}+$ Humic acid foliar spray @ $0.2 \%$ at 20 and 40 DAS & 10.33 & 10.67 & 9.33 \\
\hline $\mathrm{T}_{12}: \mathrm{T}_{4}+$ Proline foliar spray @ $50 \mathrm{mM} \mathrm{L}^{-1}$ at 20 and $40 \mathrm{DAS}$ & 10.00 & 12.00 & 9.00 \\
\hline $\mathrm{T}_{13}: \mathrm{T}_{4}+\mathrm{KNO}_{3}$ foliar spray @ $10 \mathrm{~g} \mathrm{~L}^{-1}$ at 20 and $40 \mathrm{DAS}$ & 10.33 & 13.00 & 10.00 \\
\hline SEm \pm & 0.23 & 0.23 & 0.25 \\
\hline CD@0.05 & 0.69 & 0.69 & 0.74 \\
\hline $\mathrm{CV}(\%)$ & 6.19 & 5.20 & 5.22 \\
\hline
\end{tabular}

Table.3 Influence of exogenous compounds and crop residues on actinomycetes population in soil at different stages of crop growth

\begin{tabular}{|c|c|c|c|}
\hline \multirow[t]{2}{*}{ Treatment } & \multicolumn{3}{|c|}{$\begin{array}{c}\text { Actinomycetes } \\
\left(\times 10^{4} \mathrm{CFU} \mathrm{g}^{-1} \text { soil }\right)\end{array}$} \\
\hline & Knee high & Tasseling & Harvest \\
\hline $\mathrm{T}_{1}: 100 \% \mathrm{RDFN}$ & 10.33 & 11.67 & 9.67 \\
\hline $\mathrm{T}_{2}: 125 \% \mathrm{RDFN}$ & 12.00 & 13.33 & 10.67 \\
\hline $\mathrm{T}_{3}: 100 \% \mathrm{RDFN}+25 \% \mathrm{RDN}$ as raw maize residue & 15.00 & 17.00 & 12.33 \\
\hline $\mathrm{T}_{4}: 100 \% \mathrm{RDFN}+25 \% \mathrm{RDN}$ as maize compost & 17.67 & 19.33 & 15.00 \\
\hline $\mathrm{T}_{5}: \mathrm{T}_{2}+$ Humic acid foliar spray @ $0.2 \%$ at 20 and $40 \mathrm{DAS}$ & 12.00 & 13.67 & 11.33 \\
\hline $\mathrm{T}_{6}: \mathrm{T}_{2}+$ Proline foliar spray @50 $\mathrm{mM} \mathrm{L}^{-1}$ at 20 and $40 \mathrm{DAS}$ & 12.67 & 14.00 & 12.00 \\
\hline $\mathrm{T}_{7}: \mathrm{T}_{2}+\mathrm{KNO}_{3}$ foliar spray @10 $\mathrm{g} \mathrm{L}^{-1}$ at 20 and $40 \mathrm{DAS}$ & 12.67 & 14.67 & 12.67 \\
\hline $\mathrm{T}_{8}: \mathrm{T}_{3}+$ Humic acid foliar spray @ $0.2 \%$ at 20 and 40 DAS & 14.00 & 17.33 & 13.00 \\
\hline $\mathrm{T}_{9}: \mathrm{T}_{3}+$ Proline foliar spray @ $50 \mathrm{mM} \mathrm{L}^{-1}$ at 20 and $40 \mathrm{DAS}$ & 16.33 & 17.67 & 14.33 \\
\hline $\mathrm{T}_{10}: \mathrm{T}_{3}+\mathrm{KNO}_{3}$ foliar spray @10 $\mathrm{g} \mathrm{L}^{-1}$ at 20 and $40 \mathrm{DAS}$ & 16.67 & 18.67 & 15.00 \\
\hline $\mathrm{T}_{11}: \mathrm{T}_{4}+$ Humic acid foliar spray @ $0.2 \%$ at 20 and $40 \mathrm{DAS}$ & 18.33 & 20.00 & 16.67 \\
\hline $\mathrm{T}_{12}: \mathrm{T}_{4}+$ Proline foliar spray @ $50 \mathrm{mM} \mathrm{L}^{-1}$ at 20 and $40 \mathrm{DAS}$ & 19.33 & 19.33 & 17.00 \\
\hline $\mathrm{T}_{13}: \mathrm{T}_{4}+\mathrm{KNO}_{3}$ foliar spray @ $10 \mathrm{~g} \mathrm{~L}^{-1}$ at 20 and $40 \mathrm{DAS}$ & 19.67 & 20.67 & 17.00 \\
\hline SEm \pm & 0.42 & 0.40 & 0.37 \\
\hline CD@0.05 & 1.29 & 1.22 & 1.12 \\
\hline $\mathrm{CV}(\%)$ & 4.85 & 4.18 & 4.71 \\
\hline
\end{tabular}




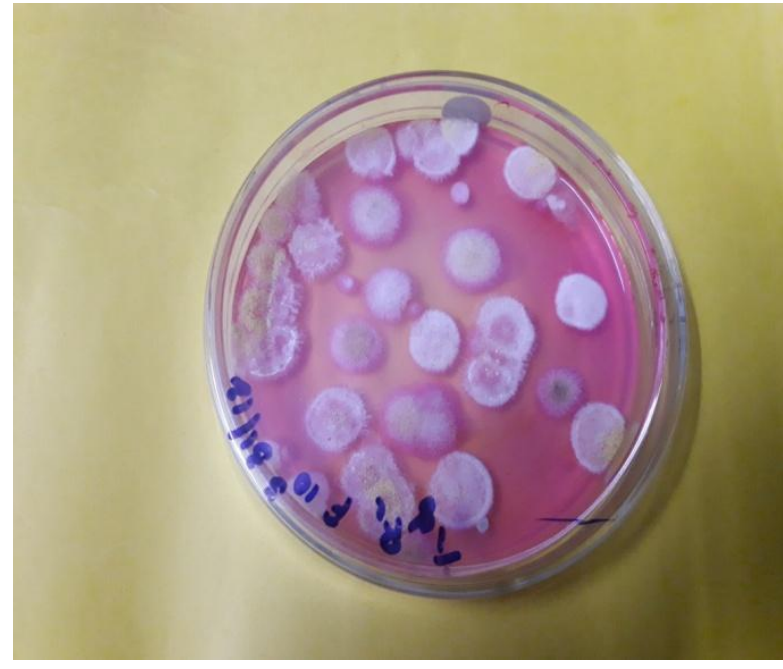

Compost

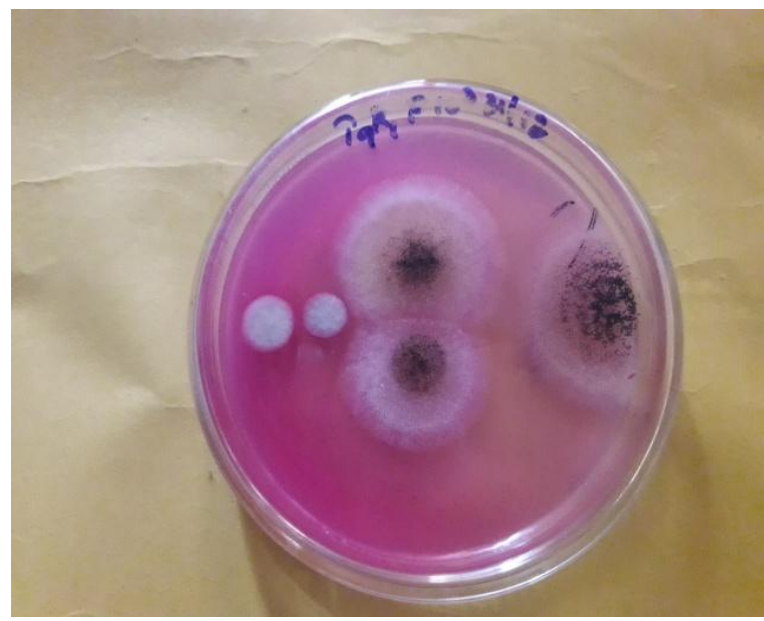

Inorganic

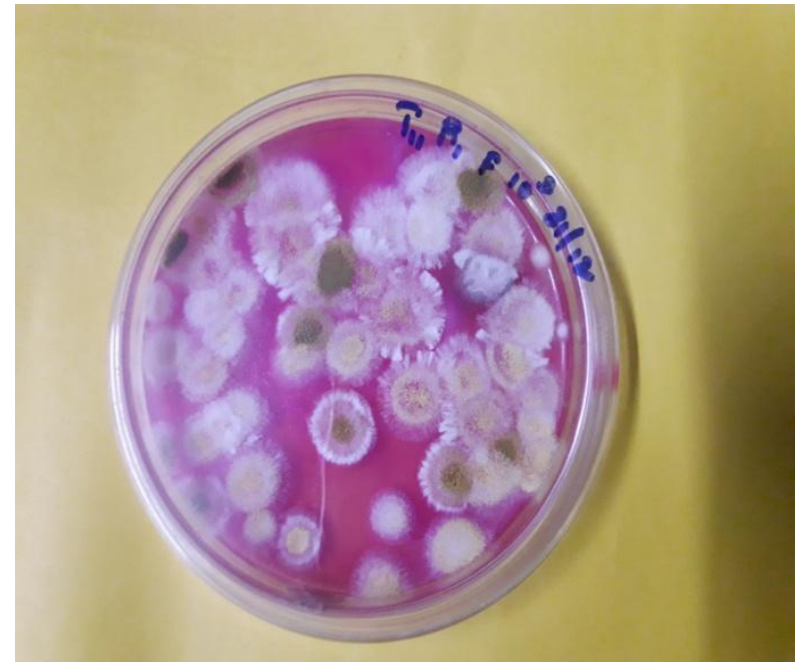

Raw residue

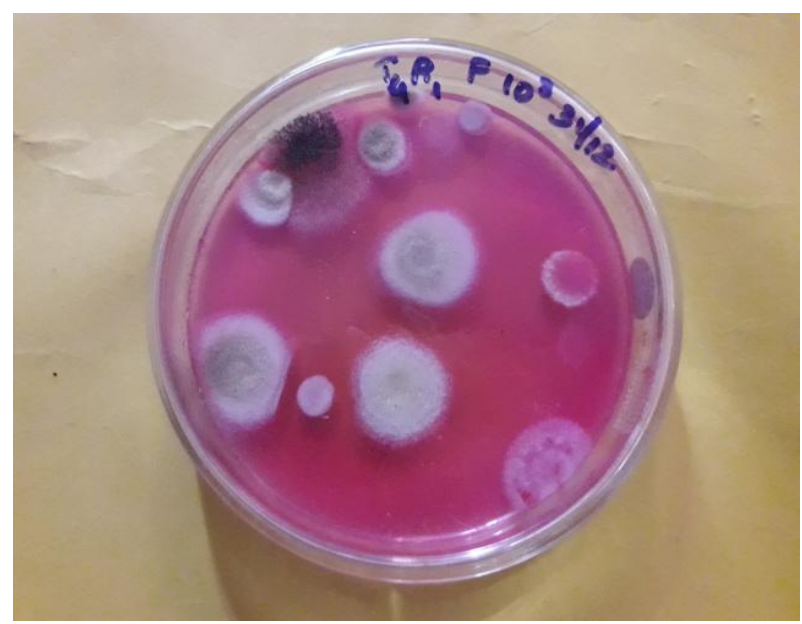

Control

Plate.1 Fungal colonies in different treatments at tasseling 


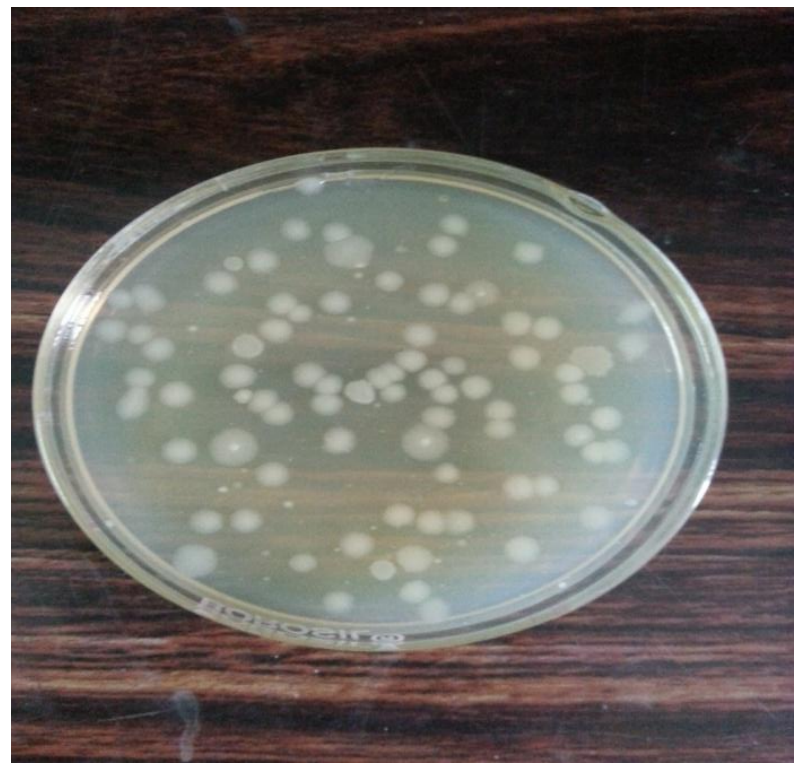

Compost

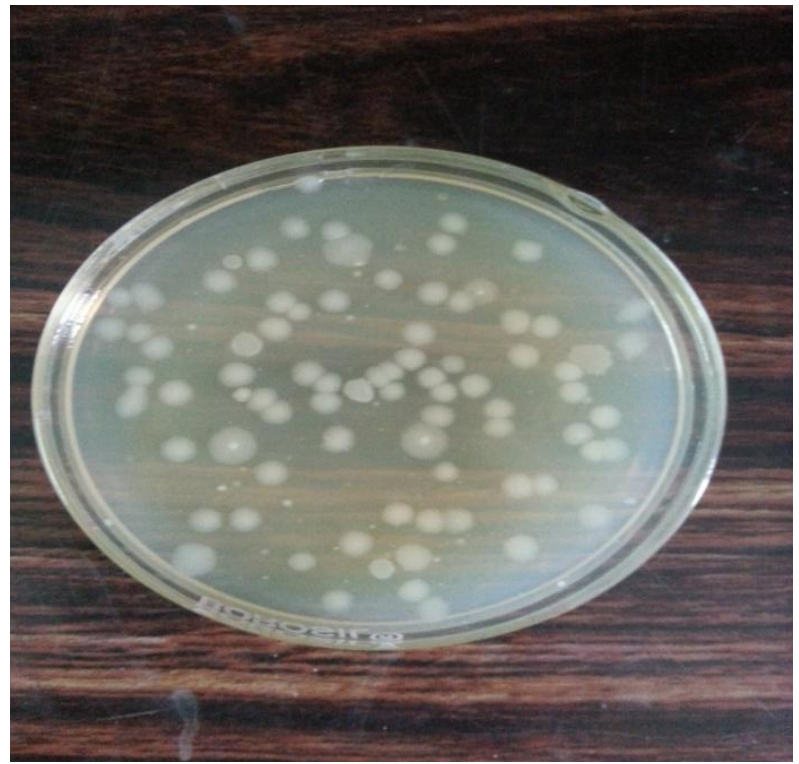

Inorganic

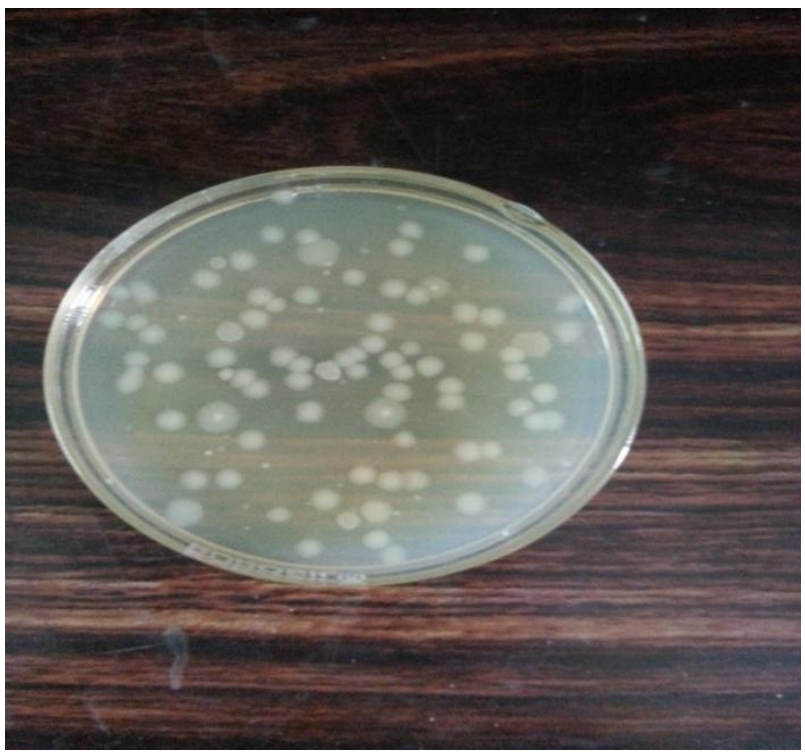

Raw residue

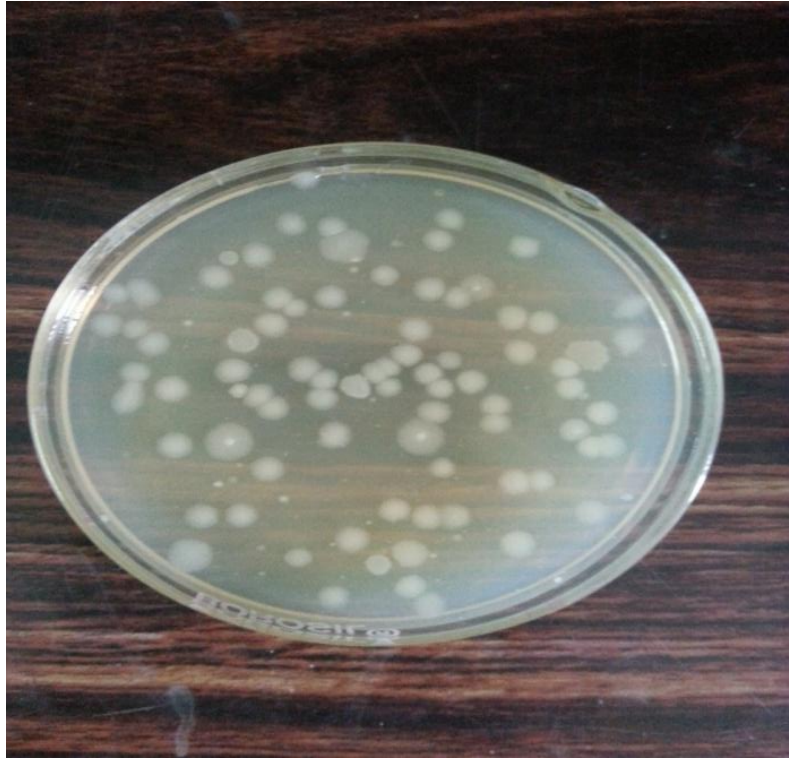

Control

Plate.2 Bacterial colonies in different treatments at tasseling 


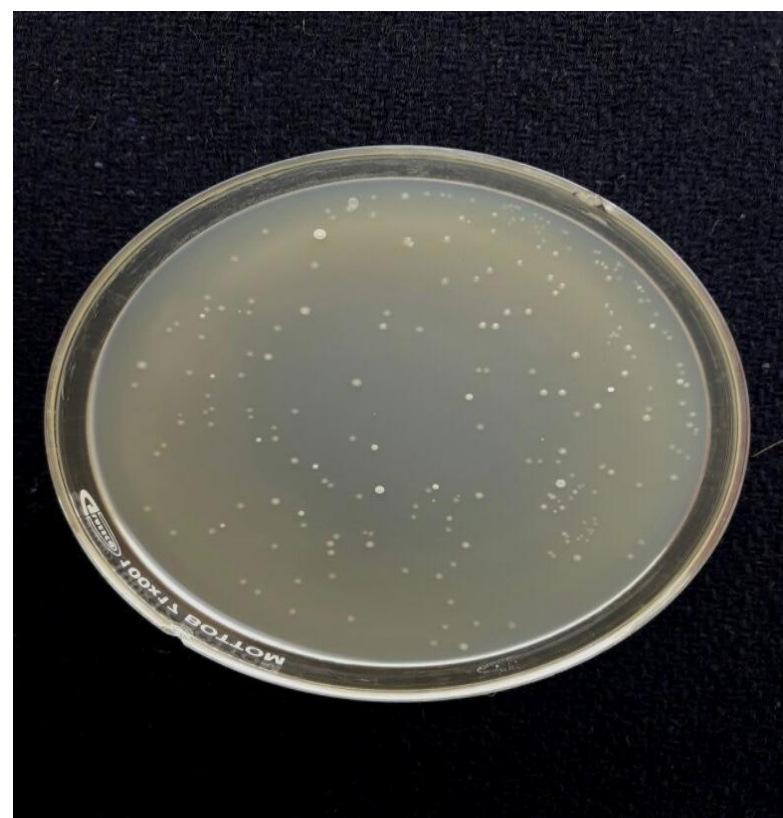

Compost

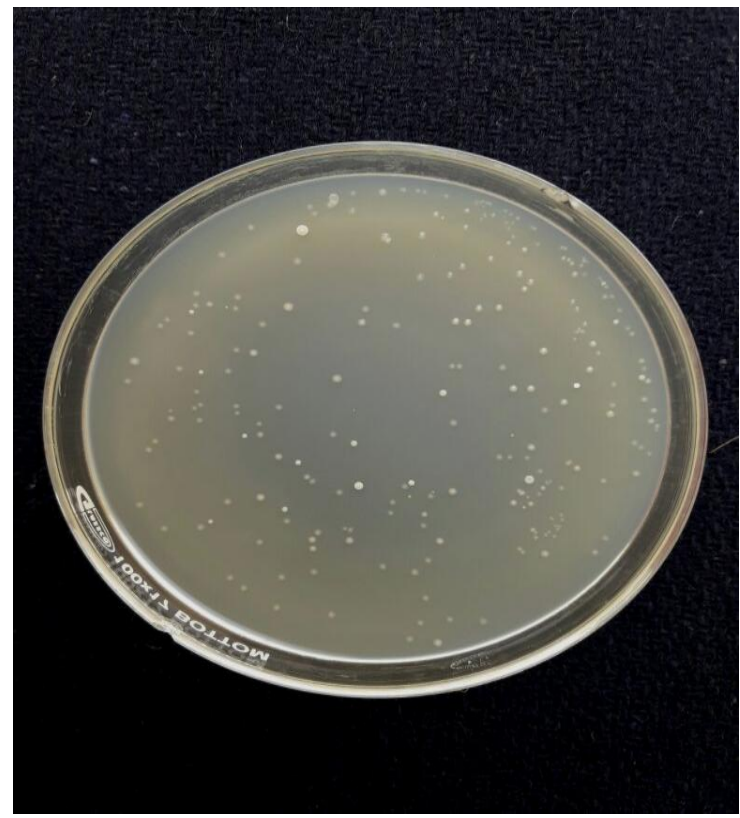

Inorganic

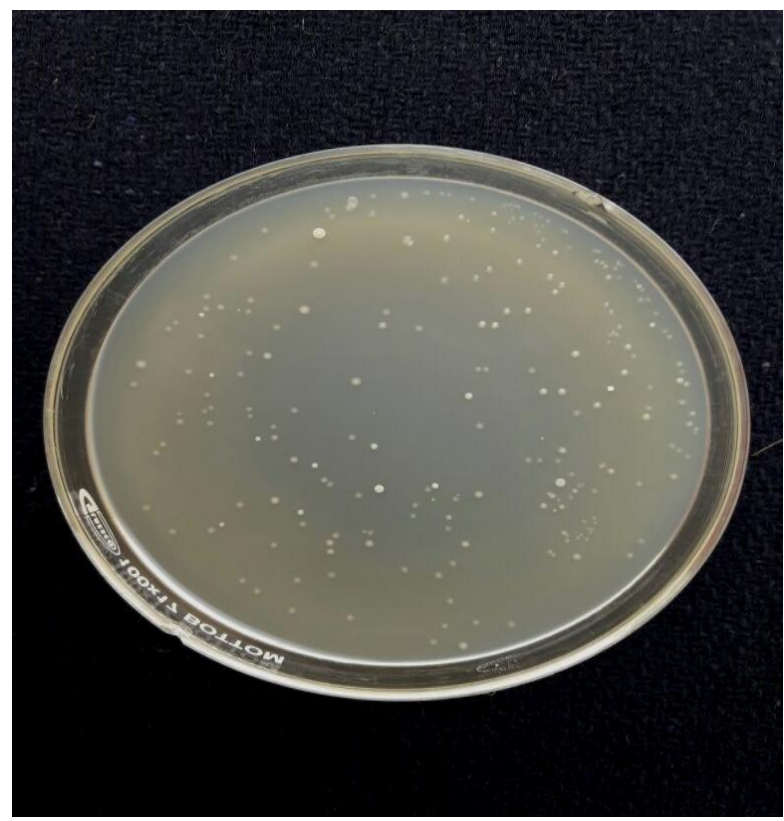

Raw residue

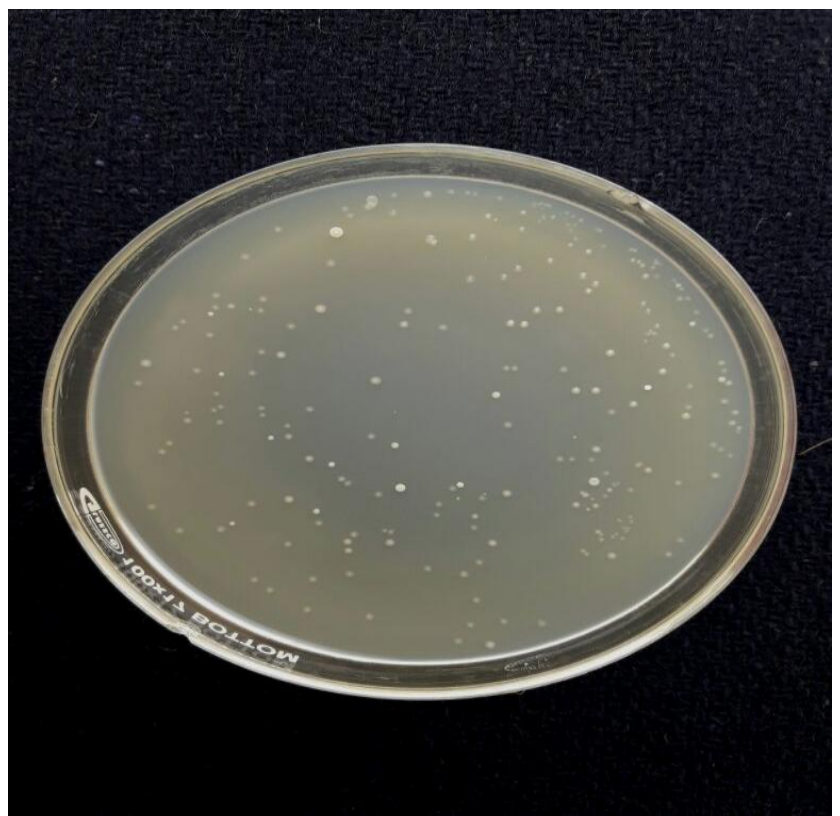

Control

Plate.3 Actinomycetes colonies in different treatments at lowering 
Table.4 Influence of exogenous compounds and crop residues on dehydrogenase activity in soil at different stages of crop growth

\begin{tabular}{|c|c|c|c|}
\hline \multirow[t]{2}{*}{ Treatment } & \multicolumn{3}{|c|}{$\begin{array}{l}\text { Dehydrogenase activity } \\
\left(\mu \mathrm{TPF} \mathrm{g}^{-1} \text { soil day }^{-1}\right)\end{array}$} \\
\hline & Knee high & Tasseling & Harvest \\
\hline $\mathrm{T}_{1}: 100 \% \mathrm{RDFN}$ & 8.20 & 12.85 & 6.77 \\
\hline $\mathrm{T}_{2}: 125 \% \mathrm{RDFN}$ & 9.34 & 15.84 & 10.80 \\
\hline $\mathrm{T}_{3}: 100 \% \mathrm{RDFN}+25 \% \mathrm{RDN}$ as raw maize residue & 18.04 & 27.78 & 14.87 \\
\hline $\mathrm{T}_{4}: 100 \% \mathrm{RDFN}+25 \% \mathrm{RDN}$ as maize compost & 22.22 & 35.45 & 16.18 \\
\hline $\mathrm{T}_{5}: \mathrm{T}_{2}+$ Humic acid foliar spray @ $0.2 \%$ at 20 and $40 \mathrm{DAS}$ & 11.38 & 16.22 & 10.77 \\
\hline $\mathrm{T}_{6}: \mathrm{T}_{2}+$ Proline foliar spray @50 mM L $\mathrm{m}^{-1}$ at 20 and $40 \mathrm{DAS}$ & 11.41 & 16.00 & 10.89 \\
\hline $\mathrm{T}_{7}: \mathrm{T}_{2}+\mathrm{KNO}_{3}$ foliar spray @ $10 \mathrm{~g} \mathrm{~L}^{-1}$ at 20 and $40 \mathrm{DAS}$ & 12.22 & 16.64 & 10.76 \\
\hline $\mathrm{T}_{8}: \mathrm{T}_{3}+$ Humic acid foliar spray @ $0.2 \%$ at 20 and 40 DAS & 18.17 & 27.22 & 14.89 \\
\hline $\mathrm{T}_{9}: \mathrm{T}_{3}+$ Proline foliar spray @ $50 \mathrm{mM} \mathrm{L}^{-1}$ at 20 and $40 \mathrm{DAS}$ & 18.09 & 26.78 & 14.56 \\
\hline $\mathrm{T}_{10}: \mathrm{T}_{3}+\mathrm{KNO}_{3}$ foliar spray @ $10 \mathrm{~g} \mathrm{~L}^{-1}$ at 20 and $40 \mathrm{DAS}$ & 18.07 & 28.33 & 14.67 \\
\hline $\mathrm{T}_{11}: \mathrm{T}_{4}+$ Humic acid foliar spray @ $0.2 \%$ at 20 and 40 DAS & 22.37 & 35.45 & 16.89 \\
\hline $\mathrm{T}_{12}: \mathrm{T}_{4}+$ Proline foliar spray @ $50 \mathrm{mM} \mathrm{L}^{-1}$ at 20 and $40 \mathrm{DAS}$ & 22.64 & 36.45 & 17.28 \\
\hline $\mathrm{T}_{13}: \mathrm{T}_{4}+\mathrm{KNO}_{3}$ foliar spray @ $10 \mathrm{~g} \mathrm{~L}^{-1}$ at 20 and $40 \mathrm{DAS}$ & 23.33 & 36.67 & 17.24 \\
\hline $\mathrm{SEm} \pm$ & 0.37 & 0.57 & 0.39 \\
\hline CD@0.05 & 1.13 & 1.71 & 1.19 \\
\hline $\mathrm{CV}(\%)$ & 3.90 & 3.84 & 4.99 \\
\hline
\end{tabular}

The critical observation of data indicated that application of organic residues especially in the form of compost was found to be favorable for the growth of microbes. Further use of exogenous compounds in general and $\mathrm{KNO}_{3}$ in particular influenced the overall activity of microbes in the presence of crop residues. Fungi were found to be more effective as they are more sensitive to saline conditions.

Crop residues provide substrate $(\mathrm{C}$ and $\mathrm{N})$ for growth and activity of soil microorganisms. Soil treated with crop residues inhabited 5 to10 times more aerobic bacteria and 1.5 to 11 times more fungi than in soils where residue is burnt or removed (Krishna et al., 2004). Addition of organic matter has been shown to increase microbial activity in saline soil (Yan and Marschner, 2012), which reduce the negative impact of salinity on microbes by providing energy for osmolytes synthesis.
Addition of readily metabolizable $\mathrm{C}$ in organic materials is likely to have been the most influential factor contributing to increased microbial population (Tejada et al., 2006). According to Pathak and Rao (1996) and Liang et al. (2005), the incorporation of organic amendments to soil stimulates dehydrogenase activity because the added material may contain intra- and extracellular enzymes and may also stimulate microbial activity in the soil.The highest dehydrogenase activity at tasseling was due to increased root exudates, mucigel and sloughed- off cells, which stimulates the microbial proliferation (Pedrazini and Mckel, 1984; Gogel, 1992). Compared to the raw materials, compost was found to have less soluble salts, greater cation exchange capacity, increased humic acid content and microbial activity and thereby high enzyme activity (Atiyeh et al., 2002).

The microbial populations and dehydrogenase 
activity of soils were significantly influenced by crop residues. Exogenous compounds in general and $\mathrm{KNO}_{3}$ in particular irrespective of source of nitrogen showed higher population of all three organism. The dehydrogenase activity was found to be significantly higher in compost added treatments while, exogenous compounds did not show any significant effect.

\section{References}

Atiyeh, R.M., Lee Edward, C.A., Arancon, N.Q and Metzger, J.D. 2002. The influence of humic acids derived from earthworm processed organic wastes on plant growth. Bioresource Technology. 84: 7-14.

Casida, L., Klein, D and Santoro,T. 1964. Soil dehydrogenase activity. Soil Science. 98: 371-376.

Dhingra, O.D., Sinclair, J.B. 2000.Basic plant pathology methods. CEC Press, London.

Gogel, S., Mishra, M.M., Hooda, I.S and Singh, R. 1992. Organic mattermicrobial biomass relationships in field experiments under tropical conditions: effects of inorganic fertilization and organic amendments. Soil Biology and Biochemistry. 24: 1081-1084.

Krishna, J.K., Mishra, B and Sarkar, A.K. 2004. Effect of plant residues incorporation on specific microbial groups and availability of some plant nutrients in soil. Journal of Indian Society of Soil Science. 48(1): 67-71.
Liang, K., John, N.M., Uwah, D.F., Iren, O.B and Patiram. 2005. Effect of integrated use of inorganic, biological and organic manures on rice productivity and soil fertility in Ultisols of Mizoram. Journal of the Indian Society of Soil Science. 54: 213-20.

Martin, J.P. 1950. Use of acid rose Bengal and streptomycin in the plate method for estimating soil fungi. Soil Science. 69: 215-232.

Paroda, K.K. 2007. Experimental Soil Microbiology. CBS publishers and distributors, New Delhi. 9-18.

Pathak, H and Rao, D.L.N . 1998. Carbon and nitrogen mineralizaton from added organic matter in saline and alkali soils. Soil Biology and Biochemistry. 30(6): 695-702.

Pedrazini, F.R and Mckel, K.L. 1984. Effect of flooding on soil dehydrogenase and alcohol dehydrogenase in rice. Soil Science and Plant Nutrition. 30: 359365.

Tejada, M., Garcia, C., Gonzalez, J.L and Hernandez, M.T. 2006. Use of organic amendment as a strategy for salne soil remediation influence on the physical, chemical and biological properties of soil. Soil Biology and Biochemistry. 38(1):1413-1421.

Yan S.I. and Marschner, M.K. 2012. Maize phenology, yield and its quality is affected by organic mulches and various irrigation regimes. International Journal of Modern Agriculture. 3: 56-59.

\section{How to cite this article:}

Anjali Bhadra Vijay, P. Prasuna Rani, P. Mohana Rao and Jayalalitha. K. 2020. Influence of Exogenous Compounds and Maize Crop Residue on Biological Activities in Salt Affected Soil. Int.J.Curr.Microbiol.App.Sci. 9(06): 4131-4139. doi: https://doi.org/10.20546/ijcmas.2020.906.485 